\title{
Curcumin and Endometriosis
}

\author{
Alexandre Vallée ${ }^{1, *(1)}$ and Yves Lecarpentier ${ }^{2}$ \\ 1 Diagnosis and Therapeutic Center, Hypertension and Cardiovascular Prevention Unit, Hôtel-Dieu Hospital, \\ AP-HP, Paris-Descartes University, 75004 Paris, France \\ 2 Centre de Recherche Clinique, Grand Hôpital de l'Est Francilien (GHEF), 77100 Meaux, France; \\ yves.c.lecarpentier@gmail.com \\ * Correspondence: alexandre.g.vallee@gmail.com
}

Received: 10 March 2020; Accepted: 23 March 2020; Published: 31 March 2020

\begin{abstract}
Endometriosis is one of the main common gynecological disorders, which is characterized by the presence of glands and stroma outside the uterine cavity. Some findings have highlighted the main role of inflammation in endometriosis by acting on proliferation, apoptosis and angiogenesis. Oxidative stress, an imbalance between reactive oxygen species and antioxidants, could have a key role in the initiation and progression of endometriosis by resulting in inflammatory responses in the peritoneal cavity. Nevertheless, the mechanisms underlying this disease are still unclear and therapies are not currently efficient. Curcumin is a major anti-inflammatory agent. Several findings have highlighted the anti-oxidant, anti-inflammatory and anti-angiogenic properties of curcumin. The purpose of this review is to summarize the potential action of curcumin in endometriosis by acting on inflammation, oxidative stress, invasion and adhesion, apoptosis and angiogenesis.
\end{abstract}

Keywords: endometriosis; curcumin; inflammation; oxidative stress

\section{Introduction}

Endometriosis is one of the main common gynecological disorders, which is characterized by the presence of glands and stroma outside the uterine cavity [1]. Between $6 \%$ and $10 \%$ of women in a reproductive age are affected by this disease. The primary symptoms of endometriosis are pelvic pain and infertility. Other symptoms are dysmenorrhea, irregular uterine bleeding, dyspareunia and dysuria [2,3]. Endometriotic lesions are often detected in the ovaries, fallopian tubes, the ligaments of the uterus, the cervical-vaginal area, the abdominal wall and umbilicus, the urinary tract and the rectum [4,5]. Environmental, endocrine, genetic and immunological factors have been observed in the initiation of endometriosis and, thus, its development [6,7]. Some findings have highlighted the main role of inflammation in endometriosis by acting on proliferation, apoptosis and angiogenesis [1]. Furthermore, oxidative stress (OS), an imbalance between reactive oxygen species (ROS) and antioxidants, could have a key role in the initiation and progression of endometriosis by resulting in inflammatory responses in the peritoneal cavity $[8,9]$.

Hormone therapy, medication and surgery are used to eradicate the symptoms in endometriotic patients. Pain-relieving, non-steroidal anti-inflammatory drugs, aromatase inhibitors, progestins, combined estrogen-progestin therapy and selective progesterone receptor modulators are the main common recommended therapies $[5,10]$. Nevertheless, the mechanisms underlying this disease are still unclear and therapies are not currently efficient. The introduction of new agents can be effective in improving the condition of patients; for example, plants are promising sources of bioactive natural components [11]. These natural compounds could be interesting strategies in therapy. Curcumin (1,7-bis(4-hydroxy-3-methoxyphenyl)-1,6-heptadiene-3,5-dione) is a natural product that presents polyphenolic phytochemical properties from the rhizome of Curcuma longa L. [12]. Curcumin has been discovered in 1815 by Vogel and Pelletier [13]. Its yellow-colored hydrophobic component 
is traditionally used in Asian countries for its several properties against pathophysiological states, including being anti-cancer [14]. Curcumin is a major anti-inflammatory agent. Studies have shown inconsistent results regarding the effects of curcumin in different diseases [15-19]; but up to now, the anti-oxidant, anti-inflammatory and anti-angiogenic properties of curcumin have been reported in several animal and human studies [20-22]. Curcumin decreases the inflammation in diseases, including cancers. Some studies have shown the role of curcumin in the prevention and the treatment of various cancers, including gastrointestinal, respiratory, lymphatic, skin and reproductive systems [23]. Curcumin use may have a major role in the control of inflammation, cell proliferation and angiogenesis [24]. The purpose of this review is to summarize the potential action of curcumin in endometriosis by acting on inflammation, oxidative stress, invasion and adhesion, apoptosis and angiogenesis.

\section{Endometriosis}

Endometriosis is a disease initiated by the growth of endometriotic glands and stroma outside of the uterus. Chronic pelvic pain and infertility can affect $10 \%$ of women [25]. Some symptoms, including dyspareunia, dysuria, dysmenorrhea and pain, characterize endometriosis. Nevertheless, the diagnosis of this disease remains uncommon [26]. Presence of endometrial tissue in ectopic lesions are associated with lymphatic/vascular metastases, celomic metaplasia and retrograde menstruation [27]. The underlying pathophysiology of endometriosis remains unclear. Endometriotic deposits have been found within the pelvis, the peritoneal surfaces of pelvic organs and within the pelvic peritoneum [28]. Organs affected by this disease are the uterus, ovaries, appendix, fallopian tubes, rectum, bladder and ureters. The deposits are named endometriomas due to old blood products. The pelvic ligaments, posterior cul-de-sac, rectovaginal septum and vesicouterine space can be also involved in endometriosis. Other deposits have been found outside the pelvis [29]. The diagnostic gold-standard of endometriosis remains laparoscopy, which is preferable to histologic confirmation [28]. Recent findings have highlighted the interest of ultrasound and MRI in the diagnosis of endometriosis [30].

\section{Pathophysiology of Endometriosis}

\subsection{Inflammation}

Inflammation has a main role in the progression of endometriosis [31]. The cascade of the different markers of inflammation leads in the upregulation of metalloproteinases, prostaglandins, cytokines and chemokines [4]. These mediators have been shown to be upregulated in peritoneal serum of endometriosis patients and in the endometrium [32-34]. In contrast, healthy cells of endometrium did not present this phenomenon [35]. Interlieukin-10 (IL-10, IL-6, IL-8, COX2 (cyclooxygenase-2), VEGF (vascular endothelial growth factor) and tumor necrosis factor $\alpha$ (TNF- $\alpha$ ) have been observed to be increased in the peritoneal fluid of endometriosis $[34,36]$. The stroma of the endometrium is associated with adhesion of extracellular matrix proteins while IL-8 and matrix metalloproteinase (MMP) have been increased [37].

In parallel, ROS production in endometriosis leads to the over-activation of the NF- $\kappa B$ pathway by stimulating angiogenesis, cell growth, inflammation and molecule adhesion [38]. Moreover, the initiation of endometriosis is associated with the upregulation of the NF- $\mathrm{kB}$ pathway, suggesting its role in cell growth, proliferation and apoptosis [39].

\subsection{Oxidative Stress}

Oxidative stress (OS) occurs because of an imbalance between ROS production and antioxidants. ROS are molecules having an unpaired electron and that are stabilized by themselves to extract electrons from some molecules in the body, such as lipids, nucleic acids and proteins.

Antioxidants are defense pathways elaborated by human to inhibit ROS production. ROS production presents a physiological interest in the body with respect to reproduction. Macrophages 
and apoptotic endometrial tissue transplanting into the peritoneal cavity, possibly by retrograde menstruation, are thought to be inducers of OS with endometriosis in women. Endometriosis and cancer have some common characteristics, including a tendency to invade tissues, an uncontrolled growth, angiogenesis processes and an ability to avoid apoptosis [40]. The long-term survival and proliferation of both endometriosis lesions and cancer cells are critically reliant upon adequate blood supply by angiogenesis and apoptosis protection. A well-established correlation between the ROS production, cell proliferation and metastatic character of tumor cells has been shown in many studies [41,42]. In both endometriosis and tumor cells, increased ROS production is associated with an augmented proliferation rate. Likewise, OS-mediated damages in the pathogenesis of endometriosis and tumor cells are similar [41]. ROS production serves as inductor of cell proliferation [43]. Increased ROS production is associated with cell proliferation through the activation of the mitogen-activated protein kinases (MAPK) pathway. The well-described association between ROS production and proliferation of tumor cells points towards ROS as a major role player in the regulation of cell proliferation in endometriosis.

ROS production enhances NF- $\mathrm{KB}$ in peritoneal macrophages leading to cell growth, angiogenesis and inflammation in endometriosis cells [44].

\subsection{Angiogenesis}

Angiogenesis is characterized by the growth of new capillaries through proliferation and migration of preexisting differentiated endothelial cells. Angiogenesis acts in both embryonic initiation and postnatal life [45,46]. Numerous pathways are involved in the different angiogenesis processes [47]. The dysfunction of growth factors plays a major role in angiogenesis [48]. VEGF may be due to physiological activators, including inflammation and hypoxia $[49,50]$. The hypoxia-inducible factor 1 $\alpha(\mathrm{HIF}-1 \alpha) /$ VEGF pathway enhances endothelial cell proliferation and migration [51].

Angiogenesis is defined by many steps: blood vessel breakdown, basement membrane degradation, surrounding extracellular matrix (ECM), endothelial cells migration and new blood vessels formation [52].

From existing vessels, new blood vessels are formed by the dissolution of aspects of native vessels. Angiopoietin-1 and 2 (ANG-1 and ANG-2) are major endothelial growth factors acting through TIE-2 receptor tyrosine kinase (RTK) expressed in endothelial cells. Under physiological conditions, ANG-1 links TIE-2 to induce an association between pericytes and endothelial cells, to stabilize the vasculature [53,54]. ANG-1 operates as a stimulator ligand for TIE-2 while ANG-2 downregulates TIE-2 phosphorylation, even in the presence of ANG-1 [55,56]. TIE-2 is a key factor of the physiological vascular development [57]. TIE-2 is a main factor of the mature vasculature homeostasis. ANG-2 is an antagonist of TIE-2 phosphorylation, which leads to destabilizing the structure of blood vessels [56,58]. In the presence of ANG-2, VEGF promotes migration and proliferation of endothelial cells and stimulates the growth of new blood vessels [59].

The angiogenesis process is composed of the dysregulation of the vessel basement membrane and the surrounding ECM [60]. The MMP enzymes family degrade components of ECM by collagenases, gelatinases, stromelysins and membrane-associated MMPs. Gelatinase-A (MMP-2) and gelatinase (MMP-9) are present in blood vessels. MMP-2 and MMP-9 have synergistic effects on the basement membrane degradation [61].

Angiogenesis has been reported in endometriosis whereas its underlying processes are still unclear in this disease [62].

\subsection{Adhesion and Invasion}

In endometriosis, molecule adhesion enhances the attachment of endometrial-like tissues to ectopic sites [63]. Numerous findings suggest that ectopic endometriotic cells have the ability to invade their surrounding environment and can metastasize in lymph nodes and in the abdominal cavity [64]. 


\subsection{Apoptosis}

Homeostasis maintenance of tissue is mainly regulated by cell death. A balance between cell proliferation and cell apoptosis maintains homeostasis in cells against diseases. Some studies have shown that apoptosis increases during the menstrual cycle to retain cell homeostasis to remove aged cells from the functional layer of the endometrium $[65,66]$. The reduction in cell death in endometriosis could be causal for the initiation of this disease $[67,68]$. The rate of apoptosis is decreased in endometrial cells of women endometriosis [69]. Moreover, the activated NF- $\mathrm{kB}$ pathway in endometriosis is associated with cell proliferation and apoptosis $[70,71]$.

\subsection{Circadian Dysregulation}

Few studies have focused on the important role of the circadian clock in endometriosis. Period 2, a clock gene, can control the expansion of human endometrial stromal cells [72]. Period 2 is a main marker of the transition from oscillatory receptivity to the non-oscillatory decidual endometrium [73]. Its inhibition is marked by a transitional phase with increased ROS production, an altered redox pathway and increased expression of decidual marker genes $[74,75]$. The modification of Period 2 expression is a response to hormonal dysregulation [76,77]. Period 2 binds estrogen receptor-alpha and inhibits estrogen-dependent proliferation in breast cancer cells [78,79]. Period 2 can promote or inhibit the cell cycle progression by a dependent hormonal regulation [72].

\section{Curcumin}

The use of dietary supplements and nutraceuticals has gained popularity over the few decades due to the increased role of, and thus interest in, natural products [80]. Curcumin, defined as bis- $\alpha$, $\beta$-unsaturated $\beta$-diketone, is a natural component well documented since 1815 . Curcumin is the active compound of turmeric or Curcuma longa L. and presents a surprising wide range of beneficial properties, such as anti-cancer features [81]. Curcumin presents some therapeutically potential roles as anti-inflammatory, anti-cancer and anti-aging [82]. In 1815, curcumin has been isolated by Vogel and Pelletier from the rhizomes of C. longa [83]. For the first time, in 1842, Vogel Jr purified curcumin. In 1910, Melabedzka et al. presented the structure of curcumin as diferuloylmethane, or 1,6-heptadiene-3,5-dione-1,7-bis (4-hydroxy-3-methoxyphenyl)-(1E,6E) [83]. In 1913, Lampe and Melobedzka have shown a method to synthesize curcumin [84]. In 1953, Srinivasan showed, by chromatography separation and quantification, the different components of curcumin [85].

The health benefits of curcumin are limited by its poor oral bioavailability that could be attributed to poor absorption, high metabolism rate and rapid systemic increase in the body. Curcumin is converted into its water-soluble metabolites and then excreted in the urine. This metabolism consists of two stages. First, a reduction in the metabolism dependent on NADPH, including the reduction of the double bonds of the heptadiene-3, 5-dione structure catalyzed by curcumin reductase dependent on NADPH. Secondly, a conjugation process was observed with monoglucuronide via a glucuronidase. These mechanisms are responsible for the low solubility and rapid metabolism of curcumin.

Although some studies have found that curcumin pharmacokinetics have shown low bioavailability [86], strong pharmacological and clinical applications have been reported [87]. Nevertheless, some of the possible ways to overcome this poor bioavailability can be counteracted by these aspects. Strategies can improve this bioavailability, such as phospholipid complexes, liposomes and nanoparticles. Some polymers have been used to prepare nanoformulations for curcumin administration to improve its biological activity [88]. Biocompatible and biodegradable polymers are used in drug delivery systems because of their low toxicity risk [89]. Advances in liposome formulations have resulted in improved treatment of drug-resistant tumors and reduced toxicity [90]. Liposomes are made by phospholipid bilayer shells and watery nuclei, resulting in the encapsulation of curcumin by both hydrophobic and hydrophilic components. Other curcumin delivery systems are used, such as nanogels [91], peptide and protein formulations [92] and cyclodextrin complexes [93]. 


\section{Actions of Curcumin in Endometriosis}

\subsection{Curcumin and Inflammation}

In endometriosis cells, the NF-кB pathway, one of the main markers of inflammation, can regulate the proliferation, apoptosis and inflammation processes observed [94]. In normal endometrium, the NF- $\mathrm{BB}$ pathway is downregulated [95] whereas its expression is increased under the various endometriosis stages [96]. An activated NF- $k B$ pathway leads to the formation of the complex NF-кB-IkappaB to activate its nuclear translocation [97]. This complex activates IL-6 and IL-8 in endometriosis [94] while its inhibition could be associated with the reduction of endometriosis development [98]. In endometriosis, NF- $\mathrm{kB}$ pathway activation is associated with better cell survival, growth and inflammatory processes [99].

Many studies have shown the value of curcumin in inflammation [100,101]. Curcumin administration can reduce the activity of the NF- $\mathrm{B}$ pathway [102]. In parallel, curcumin can downregulate the expression of TNF- $\alpha$, COX-2, IL-6 and TGF [103]. Curcumin has been shown to decrease inflammation by inhibiting the expression of inflammatory factors, such as the NF- $\kappa B$ pathway, TNF- $\alpha$, IL-1, IL-6 and IL-8, in mice macrophages [104,105].

Moreover, NF- $\kappa B$ activation is inhibited by curcumin through the blockage of $\mathrm{I}-\kappa \mathrm{B}$ phosphorylation [106] and the inactivation of the I-kB kinase complex [107]. AP-1 controls the expression of pro-inflammatory factors and antioxidant genes. The inhibition of AP-1 could be due to an action of curcumin with AP-1 and due to the inhibition of its components c-Jun and c-fos [22].

Activation of COX-2 is associated with cell proliferation and the suppression of apoptosis [108]. Some studies have shown that curcumin can inhibit COX-2 expression in animal models and cell cultures [109-111]. Curcumin can target the TNF- $\alpha$ expression to improve the growth differentiation factor-9 (GDF-9) expression in peritoneal fluid of women with endometriosis [112]. A recent study has shown that curcumin can be an interesting treatment of endometriosis by abrogating the aberrant activation of chemokines, cytokines and the NF-kB pathway [113] (Table 1).

Table 1. Effects of curcumin on inflammation, oxidative stress, angiogenesis and invasion.

\begin{tabular}{|c|c|c|c|}
\hline Action & Model & Effect & Reference \\
\hline \multirow{6}{*}{ Inflammation } & $\mathrm{Nx}$ rats & Reduction of NF-kappaB & [102] \\
\hline & Rat liver & $\begin{array}{c}\text { TNF- } \alpha, \text { COX-2, IL-6 and } \\
\text { TGF-beta }\end{array}$ & [103] \\
\hline & Mice macrophages & $\begin{array}{c}\text { NF-kB pathway, TNF- } \alpha, \text { IL-1, } \\
\text { IL-6, and IL-8 }\end{array}$ & {$[104,105]$} \\
\hline & $\begin{array}{c}\text { Human eutopic } \\
\text { endometrial stromal cells }\end{array}$ & $\begin{array}{c}\text { chemokines, cytokines and } \\
\text { NF- } \mathrm{B} \text { p pathway }\end{array}$ & [113] \\
\hline & $\begin{array}{l}\text { Human myeloid ML-1a } \\
\text { cells }\end{array}$ & $\begin{array}{l}\text { Blockage of I- } \mathrm{KB} \\
\text { phosphorylation }\end{array}$ & [106] \\
\hline & Intestinal epithelial cells & $\begin{array}{l}\text { the inactivation of I- } \mathrm{kB} \text { kinase } \\
\text { complex }\end{array}$ & [107] \\
\hline \multirow{5}{*}{ Oxidative stress } & Mice & $\begin{array}{l}\text { Reduction of ROS serum and } \\
\text { lipid peroxidation }\end{array}$ & [114] \\
\hline & Mice & $\begin{array}{l}\text { Lipid peroxidation and protein } \\
\text { oxidation }\end{array}$ & [115] \\
\hline & Nx rats & Regulation of NrF2-Keap1 & [102] \\
\hline & Mice macrophages & $\begin{array}{c}\text { Diminution of NO synthase } \\
\text { expression }\end{array}$ & [116] \\
\hline & lymphocytes & $\begin{array}{l}\text { Increase of glutathione and } \\
\text { superoxide dismutase }\end{array}$ & [117] \\
\hline
\end{tabular}


Table 1. Cont.

\begin{tabular}{|c|c|c|c|}
\hline Action & Model & Effect & Reference \\
\hline \multirow{2}{*}{ Angiogenesis } & Ectopic endometrium & Reduction of VEGF & [118] \\
\hline & Ovarian cancers & Reduction of VEGF & [119] \\
\hline \multirow{4}{*}{ Invasion and Adhesion } & $\begin{array}{l}\text { Serum mice with } \\
\text { endometriosis }\end{array}$ & $\begin{array}{l}\text { Reduction of MMP-2, MMP-3 } \\
\text { and MMP-9 expression }\end{array}$ & {$[120,121]$} \\
\hline & $\begin{array}{l}\text { Human endometriotic } \\
\text { stromal cells }\end{array}$ & $\begin{array}{l}\text { Reduction of ICAM-1 and } \\
\text { VCAM-1 expression }\end{array}$ & [94] \\
\hline & Endometriotic lesions & Reduction of TIMP-1 expression & [115] \\
\hline & Fibrosarcoma cells & $\begin{array}{c}\text { Reduction of MMP-2 and } \\
\text { MMP-9 }\end{array}$ & [122] \\
\hline \multirow[t]{3}{*}{ Apoptosis } & BALB-mice & $\begin{array}{c}\text { Increase ratio Baw/Bcl-2, } \\
\text { increase cytochrome c and } \\
\text { caspase } 9\end{array}$ & [121] \\
\hline & Rat experimental models & $\begin{array}{l}\text { Decrease of weight and volume } \\
\text { of endometriotic tissues }\end{array}$ & [118] \\
\hline & $\begin{array}{l}\text { Endometriotic cells of } \\
\text { mice }\end{array}$ & $\begin{array}{l}\text { Diminution of Bcl-2 expression, } \\
\text { diminution of mRNA and } \\
\text { protein expression of Bcl-2 }\end{array}$ & [123] \\
\hline
\end{tabular}

\subsection{Curcumin and Oxidative Stress}

OS is considered as one of the main determinants of the endometriosis process [124] (Table 1). Some studies have shown that prevention of endometriosis could be done by administration of antioxidants [125]. OS damages observed in endometriosis cells are localized in the proliferation process [126]. Superoxide dismutase activity is higher in endometriosis cells compared to healthy cells [127]. In endometriosis cells, OS can enhance the proliferation process [43] through the activation of MAPK/extracellular signal-regulated kinase (ERK), which acts on the proliferation and survival cell process. The ERK pathway is activated by ROS to enhance the proliferative response [128].

In endometriosis, there are few reports on the role of curcumin in OS. Nevertheless, administration of Letrozole-curcumin has been associated with a reduction of ROS serum and lipid peroxidation in mice [114]. Moreover, therapy by curcumin in endometriosis mice can prevent against lipid peroxidation and protein oxidation [115]. Curcumin treatment can diminish OS by regulating the Nrf2-Keap1 pathway [102].

Some evidence suggests that the curcumin antioxidant activity is comparable to vitamins $C$ and $\mathrm{E}$ [129]. Curcumin can scavenge free radicals, such as ROS and nitrogen dioxide radicals [129-131]. Curcumin can inhibit lipid peroxidation in animal models [132] and the expression of nitric oxide (NO) synthase in mice macrophages [116], and can increase glutathione and superoxide dismutase in lymphocytes [117].

\subsection{Curcumin and Angiogenesis}

Experimental studies have shown an interest in using anti-VEGF factors to inhibit the growth of endometriosis without impacting ovarian function [133] (Table 1). VEGF activation involves the stimulation of the PI3K/Akt pathway [134]. This activated pathway contributes to the initiation of angiogenesis and inhibition of apoptosis [135]. By activating HIF- $1 \alpha$ and cyclin D1, the PI3K/Akt pathway makes angiogenesis without hypoxia possible $[135,136]$. The downregulation of NME1 in the endometrium leads to activation of the PI3K/Akt pathway and to an increase in the expression of VEGF and IL-8, inducing production of new vascular cells in ectopic endometrial lesions [137]. The elevation of the PI3K/Akt pathway in endometriosis could be associated with NOS expression and OS [138]. By maintaining the fibrotic environment of endometriosis, the PI3K/Akt pathway activates the ERK 
pathway [139]. Moreover, the PI3K/Akt pathway activates the NF-kB pathway, a main activator of VEGF, to stimulate cell proliferation and angiogenesis in endometriosis [140].

Few studies have focused on the role of curcumin on angiogenesis in endometriosis. Curcumin reduces VEGF expression in ectopic endometrium but not in eutopic endometrium [118]. However, curcumin can reduce the expression of VEGF in ovarian cancers [119]. Curcumin administration is associated with the decrease of HIF- $1 \alpha$ in tumors cells $[135,141]$.

\subsection{Curcumin and Invasion and Adhesion}

The endometriotic peritoneum of women presents an overproduction of MMP, especially MMP-1, 2, 3, 9 and 11, and cellular adhesion molecules, including ICAM-1, integrins and cadherins. Molecules adhesion plays a main role in tissue attachment and, then, in the invasion of ectopic lesions. MMPs have a major role in implant progression and angiogenesis [120,142] (Table 1). MMPs are implicated in numerous reproductive processes, including menstruation, ovulation and embryo implantation [143,144]. MMP endometrial expression is low in the proliferative step, it declines in the early secretory step, but increases in the late secretory step. Progesterone is one of the major inhibitors of MMP expression while MMPs are controlled by different hormones, cytokines and growth factors. Progesterone can regulate the MMP expression by the plasminogen activator pathway that enhances the levels of plasminogen activator inhibitor (PAI)- 1 and decreases the plasmin-mediated expression of latent MMP [145-147]. The production of retinoic acid and transforming growth factor- $\beta$ (TGF- $\beta$ ) enhances the expression of tissue inhibitors of metalloproteinases (TIMPs). MMP activity is the initial mediator of maintenance and survival of lesions [148].

Curcumin action on cell invasion has been shown in several studies [100]. Curcumin administration can decrease MMP-2, MMP-3 and MMP-9 in serum mice presenting endometriosis [120,121]. Curcumin can downregulate the expression of mRNA and proteins expressing intracellular adhesion molecule 1 (ICAM-1) and vascular cell adhesion molecule 1 (VCAM-1) in a dose-dependent manner [94]. In endometriosis lesions, curcumin inhibits MMP-9 expression and can attenuate TIMP-1 expression [115]. In parallel, MMPs expressions are inhibited by curcumin in several cell types [22,149]. Curcumin decreases the activity of both MMP-2 and MMP-9 in human fibrosarcoma cells [122]. Curcumin can diminish MMP-9 expression in human intestinal epithelial cells [150], orthotopically implanted pancreatic tumors [109], ovarian tumors in nude mice [119] and can inhibit the production of MMP-3 in primary human colonic myofibroblasts [151]. Some studies have suggested that curcumin can decrease the expression of adhesion molecules, such as endothelial-leukocyte adhesion molecule 1 (ELAM-1), ICAM-1, and VCAM-l in endothelial cells and in orthotopically implanted pancreatic tumors in mice to reduce cell adhesion and invasion [109,152].

\subsection{Curcumin and Apoptosis}

The PI3K/Akt pathway is activated in endometriosis cells [153] and leads to apoptosis [154] (Table 1). A vicious circle operates between NF- $k B$ and PI3K/Akt to stimulate apoptosis [155]. The NF- $k B$ pathway inhibits the antiapoptotic role of the PI3K/Akt pathway [156]. X-linked inhibitor of apoptosis protein (XIAP) operates as caspase- 3 and caspase- 9 inhibitors and regulates the Bax-cytochrome $c$ pathway leading to an apoptosis mechanism through the inhibition of caspase-9 [157]. The PI3K/Akt signaling pathway involves the stimulation of both XIAP and B cell lymphoma extra-large (Bcl-xL) expressions. Moreover, Bcl-xL is activated by the PI3K/Akt pathway $[158,159]$. In ectopic endometriosis tissue, B-cell lymphoma 2 (BCL-2) presents some modulatory roles in apoptosis and cell proliferation [160]. $\mathrm{Bcl}-2$ can induce antiapoptotic features [161]. In normal conditions, activation of ERK1/2 stimulates the cell proliferation and the promotion of angiogenesis [162,163]. ERK1/2 stimulation can downregulate the expression of Bcl-2, leading to dysregulate mitochondrial-dependent cell death [164]. The PI3K/Akt and MAPK pathways lead to anti-apoptosis action in endometriosis [153,165].

A crosstalk operates between the ERK pathway and PI3K/Akt pathway [166,167]. The inhibition of the PI3K/Akt pathway leads to the activation of the ERK pathway [168] and the reciprocity 
is verifiable [169]. Some studies have shown the interest of co-targeting these two pathways in endometriosis [43].

Recent studies have shown that curcumin decreases the number of endometriosis stromal cells and the process of cell growth in a dose-dependent manner [170]. In BALB-mice, curcumin administration is associated with the reduction of endometriosis progression and the activation of apoptosis [121]. Curcumin administration leads to an increase in the ratio of pro-apoptotic factor Baw/anti-apoptotic factor Bcl-2, the induction of cytochrome c and caspase 9 and tumor suppressor protein p53 [121]. Moreover, curcumin decreases the weight and volume of endometriotic tissues in a dose-dependent manner in experimental rat models [118]. Nevertheless, it induces no effect in human endometriotic stromal cells [94]. In a dose-dependent manner, curcumin decreases the expression of the anti-apoptotic factor Bcl-2 [123] and diminishes the expression of mRNA and protein expression of Bcl-2 in endometrial cells of mice [171]. In parallel, curcumin inhibits cell proliferation and activates apoptosis in endometrial tumor cells [172]. Moreover, curcumin modulates the expression of VEGF [173], releases cytochrome c, stimulates caspase-8 expression and reduces Bcl-2 and cyclin-D1 expressions [104,174-177].

\subsection{Curcumin and Melatonin}

Some studies have shown that endometriosis is associated with low levels of melatonin [178]. Moreover, endometrial biopsies have presented variations in the expression of melatonin receptors (MR1A and B) depending on the ectopic tissue site [179]. The use of melatonin in endometriosis reverses the lipoperoxidation and decreases antioxidants activities observed after pinealectomy of rat models [180]. Melatonin leads to the reduction in endometriotic foci and histopathologic scores with increased levels of SOD [181]. SCID animals which received melatonin present a reduction in endometriosis lesions in oophorectomized rats [182]. This melatonin-induced decrease in endometriotic lesions is correlated with the downregulation of COX-2 levels [183]. Activities of SOD and TIMP-2 are higher after melatonin treatment while VEGF and MMP-9 levels are reduced [184]. Melatonin can lead in the regression of apoptosis through the caspase-3 pathway [185]. Moreover, treatment by melatonin results in the reduction of plasma levels of luteinizing hormone and estradiol, the promotion of differential regulation of estrogen, progesterone and androgen receptors [186]. Melatonin receptors have been observed in rat uterine endometrium, which suggests that melatonin can have a major role in the physiology of this disease [187]. The proliferation of endometrial cells can be downregulated by MT1 receptor-targeting by melatonin [188].

Few studies have focused on the potential interaction of curcumin and melatonin in endometriosis. However, recent findings have shown that co-treatment of melatonin and curcumin can decrease COX-2 expression and can repress the NF-kappaB pathway [189]. Moreover, this combination can inhibit MMP-2, MMP-9 and TIMP-2 expression [189]. Curcumin can activate sirtuin 1 (SIRT1) [134]. SIRT1 regulates the circadian rhythms. SIRT1 indirectly controls the circadian clock by downregulating the NF-KB pathway [190], inhibiting the nuclear localization of Per2 [191] and the binding to Clock/Bmal1 [192].

\section{Conclusions}

Curcumin can downregulate inflammation and OS in endometriosis. Moreover, curcumin can direct act on invasion, adhesion, apoptosis and angiogenesis in endometrial lesions. The use of curcumin could be interesting in dietary prevention and disease management for women. Nevertheless, the limited number of studies focusing on the different interactions of curcumin in endometriosis restricts its clear and immediate use in a therapeutic strategy. Future clinical trials are needed to better investigate and highlight the role of curcumin in endometriosis.

Author Contributions: Conceptualization, A.V. and Y.L.; writing—original draft preparation, A.V. and Y.L.; writing-review and editing, A.V. and Y.L. All authors have read and agreed to the published version of the manuscript.

Funding: This research received no external funding. 
Conflicts of Interest: The authors declare no conflict of interest.

\section{Abbreviations}

IL

MMP

OS

RORs

NF-KB

TNF interleukin

matrix metalloproteinase

oxidative stress

retinoid-related orphan receptors

nuclear factor $\mathrm{kB}$

tumor necrosis factor

\section{References}

1. Burney, R.O.; Giudice, L.C. Pathogenesis and pathophysiology of endometriosis. Fertil. Steril. 2012, 98, 511-519. [CrossRef] [PubMed]

2. Darling, A.M.; Chavarro, J.E.; Malspeis, S.; Harris, H.R.; Missmer, S.A. A prospective cohort study of Vitamins B, C, E, and multivitamin intake and endometriosis. J. Endometr. 2013, 5, 17-26. [CrossRef] [PubMed]

3. Tariverdian, N.; Theoharides, T.C.; Siedentopf, F.; Gutiérrez, G.; Jeschke, U.; Rabinovich, G.A.; Blois, S.M.; Arck, P.C. Neuroendocrine-immune disequilibrium and endometriosis: An interdisciplinary approach. Semin. Immunopathol. 2007, 29, 193-210. [CrossRef]

4. Vetvicka, V.; Laganà, A.S.; Salmeri, F.M.; Triolo, O.; Palmara, V.I.; Vitale, S.G.; Sofo, V.; Králíčková, M. Regulation of apoptotic pathways during endometriosis: From the molecular basis to the future perspectives. Arch. Gynecol. Obstet. 2016, 294, 897-904. [CrossRef] [PubMed]

5. Laganà, A.S.; Vitale, S.G.; Salmeri, F.M.; Triolo, O.; Ban Frangež, H.; Vrtačnik-Bokal, E.; Stojanovska, L.; Apostolopoulos, V.; Granese, R.; Sofo, V. Unus pro omnibus, omnes pro uno: A novel, evidence-based, unifying theory for the pathogenesis of endometriosis. Med. Hypotheses 2017, 103, 10-20. [CrossRef] [PubMed]

6. Kobayashi, H.; Yamada, Y.; Morioka, S.; Niiro, E.; Shigemitsu, A.; Ito, F. Mechanism of pain generation for endometriosis-associated pelvic pain. Arch. Gynecol. Obstet. 2014, 289, 13-21. [CrossRef]

7. Trovó de Marqui, A.B. Genetic polymorphisms and endometriosis: Contribution of genes that regulate vascular function and tissue remodeling. Rev. Assoc. Med. Bras. 2012, 58, 620-632. [CrossRef]

8. Agarwal, A.; Aponte-Mellado, A.; Premkumar, B.J; Shaman, A.; Gupta, S. The effects of oxidative stress on female reproduction: A review. Reprod. Biol. Endocrinol. 2012, 10, 49. [CrossRef]

9. Augoulea, A.; Mastorakos, G.; Lambrinoudaki, I.; Christodoulakos, G.; Creatsas, G. The role of the oxidative-stress in the endometriosis-related infertility. Gynecol. Endocrinol. 2009, 25, 75-81. [CrossRef]

10. Laganà, A.S.; Vitale, S.G.; Granese, R.; Palmara, V.; Ban Frangež, H.; Vrtačnik-Bokal, E.; Chiofalo, B.; Triolo, O. Clinical dynamics of Dienogest for the treatment of endometriosis: From bench to bedside. Expert Opin. Drug Metab. Toxicol. 2017, 13, 593-596. [CrossRef]

11. Kasi, P.D.; Tamilselvam, R.; Skalicka-Woźniak, K.; Nabavi, S.F.; Daglia, M.; Bishayee, A.; Pazoki-Toroudi, H.; Nabavi, S.M. Molecular targets of curcumin for cancer therapy: An updated review. Tumour Biol. 2016, 37, 13017-13028. [CrossRef] [PubMed]

12. Nabavi, S.F.; Daglia, M.; Moghaddam, A.H.; Habtemariam, S.; Nabavi, S.M. Curcumin and Liver Disease: From Chemistry to Medicine. Compr. Rev. Food Sci. Food Saf. 2014, 13, 62-77. [CrossRef]

13. Ghosh, S.; Banerjee, S.; Sil, P.C. The beneficial role of curcumin on inflammation, diabetes and neurodegenerative disease: A recent update. Food Chem. Toxicol. 2015, 83, 111-124. [CrossRef]

14. Sinha, D.; Biswas, J.; Sung, B.; Aggarwal, B.B.; Bishayee, A. Chemopreventive and chemotherapeutic potential of curcumin in breast cancer. Curr. Drug Targets 2012, 13, 1799-1819. [CrossRef] [PubMed]

15. Jiménez-Osorio, A.S.; García-Niño, W.R.; González-Reyes, S.; Álvarez-Mejía, A.E.; Guerra-León, S.; Salazar-Segovia, J.; Falcón, I.; Montes de Oca-Solano, H.; Madero, M.; Pedraza-Chaverri, J. The Effect of Dietary Supplementation with Curcumin on Redox Status and Nrf2 Activation in Patients with Nondiabetic or Diabetic Proteinuric Chronic Kidney Disease: A Pilot Study. J. Ren. Nutr. 2016, 26, 237-244. [CrossRef]

16. Chuengsamarn, S.; Rattanamongkolgul, S.; Luechapudiporn, R.; Phisalaphong, C.; Jirawatnotai, S. Curcumin extract for prevention of type 2 diabetes. Diabetes Care 2012, 35, 2121-2127. [CrossRef] 
17. Hanai, H.; Iida, T.; Takeuchi, K.; Watanabe, F.; Maruyama, Y.; Andoh, A.; Tsujikawa, T.; Fujiyama, Y.; Mitsuyama, K.; Sata, M.; et al. Curcumin maintenance therapy for ulcerative colitis: Randomized, multicenter, double-blind, placebo-controlled trial. Clin. Gastroenterol. Hepatol. 2006, 4, 1502-1506. [CrossRef]

18. Ułamek-Kozioł, M.; Czuczwar, S.J.; Januszewski, S.; Pluta, R. Substantiation for the Use of Curcumin during the Development of Neurodegeneration after Brain Ischemia. Int. J. Mol. Sci. 2020, 21, 517. [CrossRef]

19. Wang, Z.; Yang, C.; Liu, J.; Chun-Kit Tong, B.; Zhu, Z.; Malampati, S.; Gopalkrishnashetty Sreenivasmurthy, S.; Cheung, K.-H.; Iyaswamy, A.; Su, C.; et al. A Curcumin Derivative Activates TFEB and Protects against Parkinsonian Neurotoxicity in Vitro. Int. J. Mol. Sci. 2020, 21, 1515. [CrossRef]

20. Gupta, S.C.; Sung, B.; Kim, J.H.; Prasad, S.; Li, S.; Aggarwal, B.B. Multitargeting by turmeric, the golden spice: From kitchen to clinic. Mol. Nutr. Food Res. 2013, 57, 1510-1528. [CrossRef]

21. Prasad, S.; Tyagi, A.K.; Aggarwal, B.B. Recent developments in delivery, bioavailability, absorption and metabolism of curcumin: The golden pigment from golden spice. Cancer Res. Treat. 2014, 46, 2-18. [CrossRef] [PubMed]

22. Maheshwari, R.K.; Singh, A.K.; Gaddipati, J.; Srimal, R.C. Multiple biological activities of curcumin: A short review. Life Sci. 2006, 78, 2081-2087. [CrossRef] [PubMed]

23. Shanmugam, M.K.; Rane, G.; Kanchi, M.M.; Arfuso, F.; Chinnathambi, A.; Zayed, M.E.; Alharbi, S.A.; Tan, B.K.H.; Kumar, A.P.; Sethi, G. The multifaceted role of curcumin in cancer prevention and treatment. Molecules 2015, 20, 2728-2769. [CrossRef] [PubMed]

24. Block, K.I.; Gyllenhaal, C.; Lowe, L.; Amedei, A.; Amin, A.R.M.R.; Amin, A.; Aquilano, K.; Arbiser, J.; Arreola, A.; Arzumanyan, A.; et al. Designing a broad-spectrum integrative approach for cancer prevention and treatment. Semin. Cancer Biol. 2015, 35, S276-S304. [CrossRef]

25. As-Sanie, S.; Black, R.; Giudice, L.C.; Gray Valbrun, T.; Gupta, J.; Jones, B.; Laufer, M.R.; Milspaw, A.T.; Missmer, S.A.; Norman, A.; et al. Assessing research gaps and unmet needs in endometriosis. Am. J. Obstet. Gynecol. 2019, 221, 86-94. [CrossRef]

26. Ballard, K.; Lowton, K.; Wright, J. What's the delay? A qualitative study of women's experiences of reaching a diagnosis of endometriosis. Fertil. Steril. 2006, 86, 1296-1301. [CrossRef]

27. Patel, B.G.; Lenk, E.E.; Lebovic, D.I.; Shu, Y.; Yu, J.; Taylor, R.N. Pathogenesis of endometriosis: Interaction between Endocrine and inflammatory pathways. Best Pract. Res. Clin. Obstet. Gynaecol. 2018, 50, 50-60. [CrossRef]

28. Hsu, A.L.; Khachikyan, I.; Stratton, P. Invasive and noninvasive methods for the diagnosis of endometriosis. Clin. Obstet. Gynecol. 2010, 53, 413-419. [CrossRef]

29. Koninckx, P.R.; Ussia, A.; Wattiez, A.; Zupi, E.; Gomel, V. Risk Factors, Clinical Presentation, and Outcomes for Abdominal Wall Endometriosis. J. Minim. Invasive Gynecol. 2018, 25, 342-343. [CrossRef]

30. Sandré, A.; Philip, C.-A.; De-Saint-Hilaire, P.; Maissiat, E.; Bailly, F.; Cortet, M.; Dubernard, G. Comparison of three-dimensional rectosonography, rectal endoscopic sonography and magnetic resonance imaging performances in the diagnosis of rectosigmoid endometriosis. Eur. J. Obstet. Gynecol. Reprod. Biol. 2019, 240, 288-292. [CrossRef]

31. Santulli, P.; Marcellin, L.; Noël, J.-C.; Borghese, B.; Fayt, I.; Vaiman, D.; Chapron, C.; Méhats, C. Sphingosine pathway deregulation in endometriotic tissues. Fertil. Steril. 2012, 97, 904-911. [CrossRef] [PubMed]

32. Barcz, E.; Milewski, Ł.; Dziunycz, P.; Kamiński, P.; Płoski, R.; Malejczyk, J. Peritoneal cytokines and adhesion formation in endometriosis: An inverse association with vascular endothelial growth factor concentration. Fertil. Steril. 2012, 97, 1380-1386. [CrossRef] [PubMed]

33. Fan, Y.-Y.; Chen, H.-Y.; Chen, W.; Liu, Y.-N.; Fu, Y.; Wang, L.-N. Expression of inflammatory cytokines in serum and peritoneal fluid from patients with different stages of endometriosis. Gynecol. Endocrinol. 2018, 34, 507-512. [CrossRef] [PubMed]

34. Sikora, J.; Smycz-Kubańska, M.; Mielczarek-Palacz, A.; Kondera-Anasz, Z. Abnormal peritoneal regulation of chemokine activation-The role of IL-8 in pathogenesis of endometriosis. Am. J. Reprod. Immunol. 2017, 77. [CrossRef] [PubMed]

35. Lebovic, D.I.; Baldocchi, R.A.; Mueller, M.D.; Taylor, R.N. Altered expression of a cell-cycle suppressor gene, Tob-1, in endometriotic cells by cDNA array analyses. Fertil. Steril. 2002, 78, 849-854. [CrossRef]

36. Sikora, J.; Mielczarek-Palacz, A.; Kondera-Anasz, Z. Association of the Precursor of Interleukin-1 $\beta$ and Peritoneal Inflammation-Role in Pathogenesis of Endometriosis. J. Clin. Lab. Anal. 2016, 30, 831-837. [CrossRef] 
37. Kalu, E.; Sumar, N.; Giannopoulos, T.; Patel, P.; Croucher, C.; Sherriff, E.; Bansal, A. Cytokine profiles in serum and peritoneal fluid from infertile women with and without endometriosis. J. Obstet. Gynaecol. Res. 2007, 33, 490-495. [CrossRef]

38. Kaponis, A.; Iwabe, T.; Taniguchi, F.; Ito, M.; Deura, I.; Decavalas, G.; Terakawa, N.; Harada, T. The role of NF-kappaB in endometriosis. Front. Biosci. Schol. Ed. 2012, 4, 1213-1234.

39. Taniguchi, F.; Harada, T.; Miyakoda, H.; Iwabe, T.; Deura, I.; Tagashira, Y.; Miyamoto, A.; Watanabe, A.; Suou, K.; Uegaki, T.; et al. TAK1 activation for cytokine synthesis and proliferation of endometriotic cells. Mol. Cell. Endocrinol. 2009, 307, 196-204. [CrossRef]

40. Swiersz, L.M. Role of endometriosis in cancer and tumor development. Ann. N. Y. Acad. Sci. 2002, 955, 281-292. [CrossRef]

41. Laurent, A.; Nicco, C.; Chéreau, C.; Goulvestre, C.; Alexandre, J.; Alves, A.; Lévy, E.; Goldwasser, F.; Panis, Y.; Soubrane, $\mathrm{O}$; et al. Controlling tumor growth by modulating endogenous production of reactive oxygen species. Cancer Res. 2005, 65, 948-956.

42. Ishikawa, K.; Takenaga, K.; Akimoto, M.; Koshikawa, N.; Yamaguchi, A.; Imanishi, H.; Nakada, K.; Honma, Y.; Hayashi, J.-I. ROS-generating mitochondrial DNA mutations can regulate tumor cell metastasis. Science 2008, 320, 661-664. [CrossRef] [PubMed]

43. Ngô, C.; Chéreau, C.; Nicco, C.; Weill, B.; Chapron, C.; Batteux, F. Reactive oxygen species controls endometriosis progression. Am. J. Pathol. 2009, 175, 225-234. [CrossRef] [PubMed]

44. Lousse, J.-C.; Van Langendonckt, A.; Defrere, S.; Ramos, R.G.; Colette, S.; Donnez, J. Peritoneal endometriosis is an inflammatory disease. Front. Biosci. Elite Ed. 2012, 4, 23-40. [CrossRef] [PubMed]

45. Folkman, J.; Shing, Y. Angiogenesis. J. Biol. Chem. 1992, 267, 10931-10934. [PubMed]

46. Risau, W. Mechanisms of angiogenesis. Nature 1997, 386, 671-674. [CrossRef] [PubMed]

47. Zimna, A.; Kurpisz, M. Hypoxia-Inducible Factor-1 in Physiological and Pathophysiological Angiogenesis: Applications and Therapies. Biomed. Res. Int. 2015, 2015, 549412. [CrossRef]

48. Chung, A.S.; Lee, J.; Ferrara, N. Targeting the tumour vasculature: Insights from physiological angiogenesis. Nat. Rev. Cancer 2010, 10, 505-514. [CrossRef]

49. Ferrara, N.; Kerbel, R.S. Angiogenesis as a therapeutic target. Nature 2005, 438, 967-974. [CrossRef]

50. Kerbel, R.S. Tumor angiogenesis. N. Engl. J. Med. 2008, 358, 2039-2049. [CrossRef]

51. Safran, M.; Kaelin, W.G. HIF hydroxylation and the mammalian oxygen-sensing pathway. J. Clin. Investig. 2003, 111, 779-783. [CrossRef]

52. Onishi, M.; Ichikawa, T.; Kurozumi, K.; Date, I. Angiogenesis and invasion in glioma. Brain Tumor Pathol. 2011, 28, 13-24. [CrossRef] [PubMed]

53. Bergers, G.; Song, S. The role of pericytes in blood-vessel formation and maintenance. Neuro Oncol. 2005, 7, 452-464. [CrossRef] [PubMed]

54. Reiss, Y.; Machein, M.R.; Plate, K.H. The role of angiopoietins during angiogenesis in gliomas. Brain Pathol. 2005, 15, 311-317. [CrossRef]

55. Jones, N.; Iljin, K.; Dumont, D.J.; Alitalo, K. Tie receptors: New modulators of angiogenic and lymphangiogenic responses. Nat. Rev. Mol. Cell Biol. 2001, 2, 257-267. [CrossRef] [PubMed]

56. Maisonpierre, P.C.; Suri, C.; Jones, P.F.; Bartunkova, S.; Wiegand, S.J.; Radziejewski, C.; Compton, D.; McClain, J.; Aldrich, T.H.; Papadopoulos, N.; et al. Angiopoietin-2, a natural antagonist for Tie2 that disrupts in vivo angiogenesis. Science 1997, 277, 55-60. [CrossRef] [PubMed]

57. Dumont, D.J.; Gradwohl, G.; Fong, G.H.; Puri, M.C.; Gertsenstein, M.; Auerbach, A.; Breitman, M.L. Dominant-negative and targeted null mutations in the endothelial receptor tyrosine kinase, tek, reveal a critical role in vasculogenesis of the embryo. Genes Dev. 1994, 8, 1897-1909. [CrossRef]

58. Zagzag, D.; Amirnovin, R.; Greco, M.A.; Yee, H.; Holash, J.; Wiegand, S.J.; Zabski, S.; Yancopoulos, G.D.; Grumet, M. Vascular apoptosis and involution in gliomas precede neovascularization: A novel concept for glioma growth and angiogenesis. Lab. Investig. 2000, 80, 837-849. [CrossRef]

59. Hardee, M.E.; Zagzag, D. Mechanisms of glioma-associated neovascularization. Am. J. Pathol. 2012, 181, 1126-1141. [CrossRef]

60. Rooprai, H.K.; McCormick, D. Proteases and their inhibitors in human brain tumours: A review. Anticancer Res. 1997, 17, 4151-4162.

61. Lakka, S.S.; Gondi, C.S.; Rao, J.S. Proteases and glioma angiogenesis. Brain Pathol. 2005, 15, 327-341. [CrossRef] [PubMed] 
62. Wang, N.; Liu, B.; Liang, L.; Wu, Y.; Xie, H.; Huang, J.; Guo, X.; Tan, J.; Zhan, X.; Liu, Y.; et al. Antiangiogenesis therapy of endometriosis using PAMAM as a gene vector in a noninvasive animal model. Biomed. Res. Int. 2014, 2014, 546479. [CrossRef] [PubMed]

63. Kyama, C.M.; Overbergh, L.; Mihalyi, A.; Meuleman, C.; Mwenda, J.M.; Mathieu, C.; D'Hooghe, T.M. Endometrial and peritoneal expression of aromatase, cytokines, and adhesion factors in women with endometriosis. Fertil. Steril. 2008, 89, 301-310. [CrossRef] [PubMed]

64. Borghese, B.; Mondon, F.; Noël, J.-C.; Fayt, I.; Mignot, T.-M.; Vaiman, D.; Chapron, C. Gene expression profile for ectopic versus eutopic endometrium provides new insights into endometriosis oncogenic potential. Mol. Endocrinol. 2008, 22, 2557-2562. [CrossRef] [PubMed]

65. Kokawa, K.; Shikone, T.; Nakano, R. Apoptosis in the human uterine endometrium during the menstrual cycle. J. Clin. Endocrinol. Metab. 1996, 81, 4144-4147.

66. Shikone, T.; Yamoto, M.; Kokawa, K.; Yamashita, K.; Nishimori, K.; Nakano, R. Apoptosis of human corpora lutea during cyclic luteal regression and early pregnancy. J. Clin. Endocrinol. Metab. 1996, 81, 2376-2380.

67. Gebel, H.M.; Braun, D.P.; Tambur, A.; Frame, D.; Rana, N.; Dmowski, W.P. Spontaneous apoptosis of endometrial tissue is impaired in women with endometriosis. Fertil. Steril. 1998, 69, 1042-1047. [CrossRef]

68. Harada, A.; Kimura, Y.; Kojima, C.; Kono, K. Effective tolerance to serum proteins of head-tail type polycation vectors by PEGylation at the periphery of the head block. Biomacromolecules 2010, 11, 1036-1042. [CrossRef]

69. Vaskivuo, T.E.; Stenbäck, F.; Karhumaa, P.; Risteli, J.; Dunkel, L.; Tapanainen, J.S. Apoptosis and apoptosis-related proteins in human endometrium. Mol. Cell. Endocrinol. 2000, 165, 75-83. [CrossRef]

70. Iba, Y.; Harada, T.; Horie, S.; Deura, I.; Iwabe, T.; Terakawa, N. Lipopolysaccharide-promoted proliferation of endometriotic stromal cells via induction of tumor necrosis factor alpha and interleukin-8 expression. Fertil. Steril. 2004, 82 (Suppl. 3), 1036-1042. [CrossRef]

71. Khan, K.N.; Masuzaki, H.; Fujishita, A.; Kitajima, M.; Hiraki, K.; Sekine, I.; Matsuyama, T.; Ishimaru, T. Interleukin-6- and tumour necrosis factor alpha-mediated expression of hepatocyte growth factor by stromal cells and its involvement in the growth of endometriosis. Hum. Reprod. 2005, 20, 2715-2723. [CrossRef] [PubMed]

72. Muter, J.; Lucas, E.S.; Chan, Y.-W.; Brighton, P.J.; Moore, J.D.; Lacey, L.; Quenby, S.; Lam, E.W.-F.; Brosens, J.J. The clock protein period 2 synchronizes mitotic expansion and decidual transformation of human endometrial stromal cells. FASEB J. 2015, 29, 1603-1614. [CrossRef] [PubMed]

73. Uchikawa, M.; Kawamura, M.; Yamauchi, N.; Hattori, M.-A. Down-regulation of circadian clock gene period 2 in uterine endometrial stromal cells of pregnant rats during decidualization. Chronobiol. Int. 2011, 28, 1-9. [CrossRef] [PubMed]

74. Brosens, J.J.; Hayashi, N.; White, J.O. Progesterone receptor regulates decidual prolactin expression in differentiating human endometrial stromal cells. Endocrinology 1999, 140, 4809-4820. [CrossRef]

75. Al-Sabbagh, M.; Fusi, L.; Higham, J.; Lee, Y.; Lei, K.; Hanyaloglu, A.C.; Lam, E.W.-F.; Christian, M.; Brosens, J.J. NADPH oxidase-derived reactive oxygen species mediate decidualization of human endometrial stromal cells in response to cyclic AMP signaling. Endocrinology 2011, 152, 730-740. [CrossRef]

76. Nakamura, T.J.; Moriya, T.; Inoue, S.; Shimazoe, T.; Watanabe, S.; Ebihara, S.; Shinohara, K. Estrogen differentially regulates expression of Per1 and Per2 genes between central and peripheral clocks and between reproductive and nonreproductive tissues in female rats. J. Neurosci. Res. 2005, 82, 622-630. [CrossRef]

77. O'Neill, J.S.; Maywood, E.S.; Chesham, J.E.; Takahashi, J.S.; Hastings, M.H. cAMP-dependent signaling as a core component of the mammalian circadian pacemaker. Science 2008, 320, 949-953. [CrossRef]

78. Gery, S.; Virk, R.K.; Chumakov, K.; Yu, A.; Koeffler, H.P. The clock gene Per2 links the circadian system to the estrogen receptor. Oncogene 2007, 26, 7916-7920. [CrossRef]

79. Nakamura, T.J.; Sellix, M.T.; Menaker, M.; Block, G.D. Estrogen directly modulates circadian rhythms of PER2 expression in the uterus. Am. J. Physiol. Endocrinol. Metab. 2008, 295, E1025-E1031. [CrossRef]

80. Hewlings, S.J.; Kalman, D.S. Curcumin: A Review of Its' Effects on Human Health. Foods 2017, 6, 92. [CrossRef]

81. Liu, W.; Zhai, Y.; Heng, X.; Che, F.Y.; Chen, W.; Sun, D.; Zhai, G. Oral bioavailability of curcumin: Problems and advancements. J. Drug Target. 2016, 24, 694-702. [CrossRef] [PubMed]

82. Kotha, R.R.; Luthria, D.L. Curcumin: Biological, Pharmaceutical, Nutraceutical, and Analytical Aspects. Molecules 2019, 24, 2930. [CrossRef] [PubMed] 
83. Prasad, S.; Gupta, S.C.; Tyagi, A.K.; Aggarwal, B.B. Curcumin, a component of golden spice: From bedside to bench and back. Biotechnol. Adv. 2014, 32, 1053-1064. [CrossRef] [PubMed]

84. Priyadarsini, K.I. The chemistry of curcumin: From extraction to therapeutic agent. Molecules 2014, 19, 20091-20112. [CrossRef]

85. Gupta, S.C.; Patchva, S.; Koh, W.; Aggarwal, B.B. Discovery of curcumin, a component of golden spice, and its miraculous biological activities. Clin. Exp. Pharmacol. Physiol. 2012, 39, 283-299. [CrossRef]

86. Zhang, L.; Zhu, W.; Yang, C.; Guo, H.; Yu, A.; Ji, J.; Gao, Y.; Sun, M.; Zhai, G. A novel folate-modified self-microemulsifying drug delivery system of curcumin for colon targeting. Int. J. Nanomed. 2012, 7, 151-162.

87. Shen, L.; Liu, C.-C.; An, C.-Y.; Ji, H.-F. How does curcumin work with poor bioavailability? Clues from experimental and theoretical studies. Sci. Rep. 2016, 6, 20872. [CrossRef]

88. Sun, M.; Su, X.; Ding, B.; He, X.; Liu, X.; Yu, A.; Lou, H.; Zhai, G. Advances in nanotechnology-based delivery systems for curcumin. Nanomedicine 2012, 7, 1085-1100. [CrossRef]

89. Naksuriya, O.; Okonogi, S.; Schiffelers, R.M.; Hennink, W.E. Curcumin nanoformulations: A review of pharmaceutical properties and preclinical studies and clinical data related to cancer treatment. Biomaterials 2014, 35, 3365-3383. [CrossRef]

90. Malam, Y.; Loizidou, M.; Seifalian, A.M. Liposomes and nanoparticles: Nanosized vehicles for drug delivery in cancer. Trends Pharmacol. Sci. 2009, 30, 592-599. [CrossRef]

91. Lee, W.-H.; Loo, C.-Y.; Young, P.M.; Traini, D.; Mason, R.S.; Rohanizadeh, R. Recent advances in curcumin nanoformulation for cancer therapy. Expert Opin. Drug Deliv. 2014, 11, 1183-1201. [CrossRef]

92. Hatefi, A.; Amsden, B. Biodegradable injectable in situ forming drug delivery systems. J. Control. Release 2002, 80, 9-28. [CrossRef]

93. Yallapu, M.M.; Jaggi, M.; Chauhan, S.C. beta-Cyclodextrin-curcumin self-assembly enhances curcumin delivery in prostate cancer cells. Colloids Surf. B Biointerfaces 2010, 79, 113-125. [CrossRef] [PubMed]

94. Kim, K.-H.; Lee, E.N.; Park, J.K.; Lee, J.-R.; Kim, J.-H.; Choi, H.-J.; Kim, B.-S.; Lee, H.-W.; Lee, K.-S.; Yoon, S. Curcumin attenuates TNF- $\alpha$-induced expression of intercellular adhesion molecule-1, vascular cell adhesion molecule-1 and proinflammatory cytokines in human endometriotic stromal cells. Phytother. Res. 2012, 26, 1037-1047. [CrossRef] [PubMed]

95. Zhu, F.; Liu, M.; Pan, Y.; Wang, X.; Chen, Y. Small hairpin RNA targeting inhibition of NF-kB gene in endometriosis therapy of Macaca fascicularis. Zhonghua Fu Chan Ke Za Zhi 2015, 50, 48-53. [PubMed]

96. Celik, O.; Ersahin, A.; Acet, M.; Celik, N.; Baykus, Y.; Deniz, R.; Ozerol, E.; Ozerol, I. Disulfiram, as a candidate NF- $\mathrm{KB}$ and proteasome inhibitor, prevents endometriotic implant growing in a rat model of endometriosis. Eur. Rev. Med. Pharmacol. Sci. 2016, 20, 4380-4389. [PubMed]

97. González-Ramos, R.; Van Langendonckt, A.; Defrère, S.; Lousse, J.-C.; Colette, S.; Devoto, L.; Donnez, J. Involvement of the nuclear factor-kB pathway in the pathogenesis of endometriosis. Fertil. Steril. 2010, 94, 1985-1994. [CrossRef]

98. Soares, S.R.; Martínez-Varea, A.; Hidalgo-Mora, J.J.; Pellicer, A. Pharmacologic therapies in endometriosis: A systematic review. Fertil. Steril. 2012, 98, 529-555. [CrossRef]

99. Reis, F.M.; Petraglia, F.; Taylor, R.N. Endometriosis: Hormone regulation and clinical consequences of chemotaxis and apoptosis. Hum. Reprod. Update 2013, 19, 406-418. [CrossRef]

100. Arablou, T.; Kolahdouz-Mohammadi, R. Curcumin and endometriosis: Review on potential roles and molecular mechanisms. Biomed. Pharmacother. 2018, 97, 91-97. [CrossRef]

101. Vitali, D.; Bagri, P.; Wessels, J.M.; Arora, M.; Ganugula, R.; Parikh, A.; Mandur, T.; Felker, A.; Garg, S.; Kumar, M.N.V.R.; et al. Curcumin Can Decrease Tissue Inflammation and the Severity of HSV-2 Infection in the Female Reproductive Mucosa. Int. J. Mol. Sci. 2020, 21, 337. [CrossRef] [PubMed]

102. Soetikno, V.; Sari, F.R.; Lakshmanan, A.P.; Arumugam, S.; Harima, M.; Suzuki, K.; Kawachi, H.; Watanabe, K. Curcumin alleviates oxidative stress, inflammation, and renal fibrosis in remnant kidney through the Nrf2-keap1 pathway. Mol. Nutr. Food Res. 2013, 57, 1649-1659. [CrossRef] [PubMed]

103. Fu, Y.; Zheng, S.; Lin, J.; Ryerse, J.; Chen, A. Curcumin protects the rat liver from CCl4-caused injury and fibrogenesis by attenuating oxidative stress and suppressing inflammation. Mol. Pharmacol. 2008, 73, 399-409. [CrossRef] [PubMed]

104. Epstein, J.; Sanderson, I.R.; Macdonald, T.T. Curcumin as a therapeutic agent: The evidence from in vitro, animal and human studies. Br. J. Nutr. 2010, 103, 1545-1557. [CrossRef] [PubMed] 
105. Woo, H.-M.; Kang, J.-H.; Kawada, T.; Yoo, H.; Sung, M.-K.; Yu, R. Active spice-derived components can inhibit inflammatory responses of adipose tissue in obesity by suppressing inflammatory actions of macrophages and release of monocyte chemoattractant protein-1 from adipocytes. Life Sci. 2007, 80, 926-931. [CrossRef]

106. Singh, S.; Aggarwal, B.B. Activation of transcription factor NF-kappa B is suppressed by curcumin (diferuloylmethane) [corrected]. J. Biol. Chem. 1995, 270, 24995-25000. [CrossRef] [PubMed]

107. Jobin, C.; Bradham, C.A.; Russo, M.P.; Juma, B.; Narula, A.S.; Brenner, D.A.; Sartor, R.B. Curcumin blocks cytokine-mediated NF-kappa B activation and proinflammatory gene expression by inhibiting inhibitory factor I-kappa B kinase activity. J. Immunol. 1999, 163, 3474-3483.

108. Williams, C.S.; Mann, M.; DuBois, R.N. The role of cyclooxygenases in inflammation, cancer, and development. Oncogene 1999, 18, 7908-7916. [CrossRef]

109. Kunnumakkara, A.B.; Guha, S.; Krishnan, S.; Diagaradjane, P.; Gelovani, J.; Aggarwal, B.B. Curcumin potentiates antitumor activity of gemcitabine in an orthotopic model of pancreatic cancer through suppression of proliferation, angiogenesis, and inhibition of nuclear factor-kappaB-regulated gene products. Cancer Res. 2007, 67, 3853-3861. [CrossRef]

110. Chun, K.-S.; Keum, Y.-S.; Han, S.S.; Song, Y.-S.; Kim, S.-H.; Surh, Y.-J. Curcumin inhibits phorbol ester-induced expression of cyclooxygenase-2 in mouse skin through suppression of extracellular signal-regulated kinase activity and NF-kappaB activation. Carcinogenesis 2003, 24, 1515-1524. [CrossRef]

111. Aggarwal, B.B.; Shishodia, S.; Takada, Y.; Banerjee, S.; Newman, R.A.; Bueso-Ramos, C.E.; Price, J.E. Curcumin suppresses the paclitaxel-induced nuclear factor-kappaB pathway in breast cancer cells and inhibits lung metastasis of human breast cancer in nude mice. Clin. Cancer Res. 2005, 11, 7490-7498. [CrossRef] [PubMed]

112. Hendarto, H.; Yohanes Ardianta Widyanugraha, M.; Widjiati, W. Curcumin improves growth factors expression of bovine cumulus-oocyte complexes cultured in peritoneal fluid of women with endometriosis. Int. J. Reprod. Biomed. 2018, 16. [CrossRef] [PubMed]

113. Chowdhury, I.; Banerjee, S.; Driss, A.; Xu, W.; Mehrabi, S.; Nezhat, C.; Sidell, N.; Taylor, R.N.; Thompson, W.E. Curcumin attenuates proangiogenic and proinflammatory factors in human eutopic endometrial stromal cells through the NF-кB signaling pathway. J. Cell. Physiol. 2019, 234, 6298-6312. [CrossRef] [PubMed]

114. Kumar Jana, S. Letrozole and Curcumin Loaded-PLGA Nanoparticles: A Therapeutic Strategy for Endometriosis. J. Nanomed. Biother. Discov. 2014, 4. [CrossRef]

115. Swarnakar, S.; Paul, S. Curcumin arrests endometriosis by downregulation of matrix metalloproteinase- 9 activity. Indian J. Biochem. Biophys. 2009, 46, 59-65.

116. Liang, G.; Zhou, H.; Wang, Y.; Gurley, E.C.; Feng, B.; Chen, L.; Xiao, J.; Yang, S.; Li, X. Inhibition of LPS-induced production of inflammatory factors in the macrophages by mono-carbonyl analogues of curcumin. J. Cell. Mol. Med. 2009, 13, 3370-3379. [CrossRef]

117. Srinivasan, M.; Rajendra Prasad, N.; Menon, V.P. Protective effect of curcumin on gamma-radiation induced DNA damage and lipid peroxidation in cultured human lymphocytes. Mutat. Res. 2006, 611, 96-103. [CrossRef]

118. Zhang, Y.; Cao, H.; Hu, Y.-Y.; Wang, H.; Zhang, C.-J. Inhibitory effect of curcumin on angiogenesis in ectopic endometrium of rats with experimental endometriosis. Int. J. Mol. Med. 2011, 27, 87-94. [CrossRef]

119. Lin, Y.G.; Kunnumakkara, A.B.; Nair, A.; Merritt, W.M.; Han, L.Y.; Armaiz-Pena, G.N.; Kamat, A.A.; Spannuth, W.A.; Gershenson, D.M.; Lutgendorf, S.K.; et al. Curcumin inhibits tumor growth and angiogenesis in ovarian carcinoma by targeting the nuclear factor-kappaB pathway. Clin. Cancer Res. 2007, 13, 3423-3430. [CrossRef]

120. Jana, S.; Rudra, D.S.; Paul, S.; Snehasikta, S. Curcumin delays endometriosis development by inhibiting MMP-2 activity. Indian J. Biochem. Biophys. 2012, 49, 342-348.

121. Jana, S.; Paul, S.; Swarnakar, S. Curcumin as anti-endometriotic agent: Implication of MMP-3 and intrinsic apoptotic pathway. Biochem. Pharmacol. 2012, 83, 797-804. [CrossRef] [PubMed]

122. Yodkeeree, S.; Garbisa, S.; Limtrakul, P. Tetrahydrocurcumin inhibits HT1080 cell migration and invasion via downregulation of MMPs and uPA. Acta Pharmacol. Sin. 2008, 29, 853-860. [CrossRef] [PubMed]

123. Yu, Z.; Shah, D.M. Curcumin down-regulates Ets-1 and Bcl-2 expression in human endometrial carcinoma HEC-1-A cells. Gynecol. Oncol. 2007, 106, 541-548. [CrossRef] [PubMed]

124. Samimi, M.; Pourhanifeh, M.H.; Mehdizadehkashi, A.; Eftekhar, T.; Asemi, Z. The role of inflammation, oxidative stress, angiogenesis, and apoptosis in the pathophysiology of endometriosis: Basic science and new insights based on gene expression. J. Cell. Physiol. 2019, 234, 19384-19392. [CrossRef] [PubMed] 
125. Van Langendonckt, A.; Casanas-Roux, F.; Donnez, J. Oxidative stress and peritoneal endometriosis. Fertil. Steril. 2002, 77, 861-870. [CrossRef]

126. Tosti, C.; Pinzauti, S.; Santulli, P.; Chapron, C.; Petraglia, F. Pathogenetic Mechanisms of Deep Infiltrating Endometriosis. Reprod. Sci. 2015, 22, 1053-1059. [CrossRef]

127. Oner-Iyidoğan, Y.; Koçak, H.; Gürdöl, F.; Korkmaz, D.; Buyru, F. Indices of oxidative stress in eutopic and ectopic endometria of women with endometriosis. Gynecol. Obstet. Investig. 2004, 57, $214-217$.

128. Andrade, S.S.; Azevedo, A.D.C.; Monasterio, I.C.G.; Paredes-Gamero, E.J.; Gonçalves, G.A.; Bonetti, T.C.; Albertoni, G.; Schor, E.; Barreto, J.A.; Luiza Oliva, M.; et al. 17 $\beta$-Estradiol and steady-state concentrations of $\mathrm{H}_{2} \mathrm{O}_{2}$ : Antiapoptotic effect in endometrial cells from patients with endometriosis. Free Radic. Biol. Med. 2013, 60, 63-72. [CrossRef]

129. Reddy, A.C.; Lokesh, B.R. Studies on the inhibitory effects of curcumin and eugenol on the formation of reactive oxygen species and the oxidation of ferrous iron. Mol. Cell. Biochem. 1994, 137, 1-8. [CrossRef]

130. Unnikrishnan, M.K.; Rao, M.N. Curcumin inhibits nitrogen dioxide induced oxidation of hemoglobin. Mol. Cell. Biochem. 1995, 146, 35-37. [CrossRef]

131. Sreejayan; Rao, M.N. Nitric oxide scavenging by curcuminoids. J. Pharm. Pharmacol. 1997, 49, $105-107$. [CrossRef] [PubMed]

132. Sreejayan; Rao, M.N. Curcuminoids as potent inhibitors of lipid peroxidation. J. Pharm. Pharmacol. 1994, 46, 1013-1016. [CrossRef] [PubMed]

133. Liu, S.; Xin, X.; Hua, T.; Shi, R.; Chi, S.; Jin, Z.; Wang, H. Efficacy of Anti-VEGF/VEGFR Agents on Animal Models of Endometriosis: A Systematic Review and Meta-Analysis. PLoS ONE 2016, 11, e0166658. [CrossRef] [PubMed]

134. Vallée, A.; Lecarpentier, Y.; Vallée, J.-N. Curcumin: A therapeutic strategy in cancers by inhibiting the canonical WNT/ $\beta$-catenin pathway. J. Exp. Clin. Cancer Res. 2019, 38, 323. [CrossRef] [PubMed]

135. Vallée, A.; Guillevin, R.; Vallée, J.-N. Vasculogenesis and angiogenesis initiation under normoxic conditions through Wnt/ $\beta$-catenin pathway in gliomas. Rev. Neurosci. 2018, 29, 71-91. [CrossRef] [PubMed]

136. Mayerhofer, M.; Valent, P.; Sperr, W.R.; Griffin, J.D.; Sillaber, C. BCR/ABL induces expression of vascular endothelial growth factor and its transcriptional activator, hypoxia inducible factor-1alpha, through a pathway involving phosphoinositide 3-kinase and the mammalian target of rapamycin. Blood 2002, 100, 3767-3775. [CrossRef]

137. Chang, K.-K.; Liu, L.-B.; Jin, L.-P.; Meng, Y.-H.; Shao, J.; Wang, Y.; Mei, J.; Li, M.-Q.; Li, D.-J. NME1 suppression of endometrial stromal cells promotes angiogenesis in the endometriotic milieu via stimulating the secretion of IL-8 and VEGF. Int. J. Clin. Exp. Pathol. 2013, 6, 2030-2038.

138. Yeo, S.G.; Won, Y.S.; Lee, H.Y.; Kim, Y.I.; Lee, J.-W.; Park, D.C. Increased expression of pattern recognition receptors and nitric oxide synthase in patients with endometriosis. Int. J. Med. Sci. 2013, 10, 1199-1208. [CrossRef]

139. Matsuzaki, S.; Darcha, C. Co-operation between the AKT and ERK signaling pathways may support growth of deep endometriosis in a fibrotic microenvironment in vitro. Hum. Reprod. 2015, 30, 1606-1616. [CrossRef]

140. Zhang, H.; Zhao, X.; Liu, S.; Li, J.; Wen, Z.; Li, M. 17betaE2 promotes cell proliferation in endometriosis by decreasing PTEN via NFkappaB-dependent pathway. Mol. Cell. Endocrinol. 2010, 317, 31-43. [CrossRef]

141. Vallée, A.; Lecarpentier, Y.; Guillevin, R.; Vallée, J.-N. Thermodynamics in Gliomas: Interactions between the Canonical WNT/Beta-Catenin Pathway and PPAR Gamma. Front. Physiol. 2017, 8, 352. [CrossRef] [PubMed]

142. Hadler-Olsen, E.; Winberg, J.-O.; Uhlin-Hansen, L. Matrix metalloproteinases in cancer: Their value as diagnostic and prognostic markers and therapeutic targets. Tumour Biol. 2013, 34, 2041-2051. [CrossRef] [PubMed]

143. Marbaix, E.; Kokorine, I.; Henriet, P.; Donnez, J.; Courtoy, P.J.; Eeckhout, Y. The expression of interstitial collagenase in human endometrium is controlled by progesterone and by oestradiol and is related to menstruation. Biochem. J. 1995, 305 Pt 3, 1027-1030. [CrossRef]

144. Hulboy, D.L.; Rudolph, L.A.; Matrisian, L.M. Matrix metalloproteinases as mediators of reproductive function. Mol. Hum. Reprod. 1997, 3, 27-45. [CrossRef] [PubMed]

145. Rodgers, W.H.; Matrisian, L.M.; Giudice, L.C.; Dsupin, B.; Cannon, P.; Svitek, C.; Gorstein, F.; Osteen, K.G. Patterns of matrix metalloproteinase expression in cycling endometrium imply differential functions and regulation by steroid hormones. J. Clin. Investig. 1994, 94, 946-953. [CrossRef] [PubMed] 
146. Bruner, K.L.; Eisenberg, E.; Gorstein, F.; Osteen, K.G. Progesterone and transforming growth factor-beta coordinately regulate suppression of endometrial matrix metalloproteinases in a model of experimental endometriosis. Steroids 1999, 64, 648-653. [CrossRef]

147. Spuijbroek, M.D.; Dunselman, G.A.; Menheere, P.P.; Evers, J.L. Early endometriosis invades the extracellular matrix. Fertil. Steril. 1992, 58, 929-933. [CrossRef]

148. Stamenkovic, I. Extracellular matrix remodelling: The role of matrix metalloproteinases. J. Pathol. 2003, 200, 448-464. [CrossRef]

149. Hahm, E.-R.; Gho, Y.S.; Park, S.; Park, C.; Kim, K.-W.; Yang, C.-H. Synthetic curcumin analogs inhibit activator protein-1 transcription and tumor-induced angiogenesis. Biochem. Biophys. Res. Commun. 2004, 321, 337-344. [CrossRef]

150. Claramunt, R.M.; Bouissane, L.; Cabildo, M.P.; Cornago, M.P.; Elguero, J.; Radziwon, A.; Medina, C. Synthesis and biological evaluation of curcuminoid pyrazoles as new therapeutic agents in inflammatory bowel disease: Effect on matrix metalloproteinases. Bioorg. Med. Chem. 2009, 17, 1290-1296. [CrossRef]

151. Epstein, J.; Docena, G.; MacDonald, T.T.; Sanderson, I.R. Curcumin suppresses p 38 mitogen-activated protein kinase activation, reduces IL-1beta and matrix metalloproteinase-3 and enhances IL-10 in the mucosa of children and adults with inflammatory bowel disease. Br. J. Nutr. 2010, 103, 824-832. [CrossRef] [PubMed]

152. Gupta, B.; Ghosh, B. Curcuma longa inhibits TNF-alpha induced expression of adhesion molecules on human umbilical vein endothelial cells. Int. J. Immunopharmacol. 1999, 21, 745-757. [CrossRef]

153. Cinar, O.; Seval, Y.; Uz, Y.H.; Cakmak, H.; Ulukus, M.; Kayisli, U.A.; Arici, A. Differential regulation of Akt phosphorylation in endometriosis. Reprod. Biomed. Online 2009, 19, 864-871. [CrossRef] [PubMed]

154. Brazil, D.P.; Yang, Z.-Z.; Hemmings, B.A. Advances in protein kinase B signalling: AKTion on multiple fronts. Trends Biochem. Sci. 2004, 29, 233-242. [CrossRef]

155. Meng, F.; Liu, L.; Chin, P.C.; D’Mello, S.R. Akt is a downstream target of NF-kappa B. J. Biol. Chem. 2002, 277, 29674-29680. [CrossRef]

156. Romashkova, J.A.; Makarov, S.S. NF-kappaB is a target of AKT in anti-apoptotic PDGF signalling. Nature 1999, 401, 86-90. [CrossRef]

157. Deveraux, Q.L.; Roy, N.; Stennicke, H.R.; Van Arsdale, T.; Zhou, Q.; Srinivasula, S.M.; Alnemri, E.S.; Salvesen, G.S.; Reed, J.C. IAPs block apoptotic events induced by caspase- 8 and cytochrome c by direct inhibition of distinct caspases. EMBO J. 1998, 17, 2215-2223. [CrossRef]

158. Jones, R.G.; Parsons, M.; Bonnard, M.; Chan, V.S.; Yeh, W.C.; Woodgett, J.R.; Ohashi, P.S. Protein kinase B regulates T lymphocyte survival, nuclear factor kappaB activation, and Bcl-X(L) levels in vivo. J. Exp. Med. 2000, 191, 1721-1734. [CrossRef]

159. Zong, W.X.; Edelstein, L.C.; Chen, C.; Bash, J.; Gélinas, C. The prosurvival Bcl-2 homolog Bfl-1/A1 is a direct transcriptional target of NF-kappaB that blocks TNFalpha-induced apoptosis. Genes Dev. 1999, 13, 382-387. [CrossRef]

160. Subramaniam, S.; Unsicker, K. ERK and cell death: ERK1/2 in neuronal death. FEBS J. 2010, 277, $22-29$. [CrossRef]

161. Mourtzikou, A.; Kosmas, K.; Marouga, A.; Stamouli, M.; Pouliakis, A.; Karakitsos, P. The use of an immunocytochemical double-labeling staining can display the distribution of Bcl-2/Ki-67 cells in endometrial adenocarcinomas as well as in normal endometrium. Clin. Lab. 2012, 58, 133-144.

162. Andradas, C.; Caffarel, M.M.; Pérez-Gómez, E.; Salazar, M.; Lorente, M.; Velasco, G.; Guzmán, M.; Sánchez, C. The orphan $G$ protein-coupled receptor GPR55 promotes cancer cell proliferation via ERK. Oncogene 2011, 30, 245-252. [CrossRef] [PubMed]

163. Cai, W.-J.; Wang, M.-J.; Ju, L.-H.; Wang, C.; Zhu, Y.-C. Hydrogen sulfide induces human colon cancer cell proliferation: Role of Akt, ERK and p21. Cell Biol. Int. 2010, 34, 565-572. [CrossRef] [PubMed]

164. Wu, Z.; Wu, L.; Tashiro, S.; Onodera, S.; Ikejima, T. Phosphorylated extracellular signal-regulated kinase up-regulated p53 expression in shikonin-induced HeLa cell apoptosis. Chin. Med. J. 2005, 118, 671-677. [PubMed]

165. Yin, X.; Pavone, M.E.; Lu, Z.; Wei, J.; Kim, J.J. Increased activation of the PI3K/AKT pathway compromises decidualization of stromal cells from endometriosis. J. Clin. Endocrinol. Metab. 2012, 97, E35-E43. [CrossRef] [PubMed] 
166. Saini, K.S.; Loi, S.; de Azambuja, E.; Metzger-Filho, O.; Saini, M.L.; Ignatiadis, M.; Dancey, J.E.; Piccart-Gebhart, M.J. Targeting the PI3K/AKT/mTOR and Raf/MEK/ERK pathways in the treatment of breast cancer. Cancer Treat. Rev. 2013, 39, 935-946. [CrossRef]

167. De Luca, A.; Maiello, M.R.; D'Alessio, A.; Pergameno, M.; Normanno, N. The RAS/RAF/MEK/ERK and the PI3K/AKT signalling pathways: Role in cancer pathogenesis and implications for therapeutic approaches. Expert Opin. Ther. Targets 2012, 16 (Suppl. 2), S17-S27. [CrossRef]

168. Serra, V.; Scaltriti, M.; Prudkin, L.; Eichhorn, P.J.A.; Ibrahim, Y.H.; Chandarlapaty, S.; Markman, B.; Rodriguez, O.; Guzman, M.; Rodriguez, S.; et al. PI3K inhibition results in enhanced HER signaling and acquired ERK dependency in HER2-overexpressing breast cancer. Oncogene 2011, 30, 2547-2557. [CrossRef]

169. Hoeflich, K.P.; O’Brien, C.; Boyd, Z.; Cavet, G.; Guerrero, S.; Jung, K.; Januario, T.; Savage, H.; Punnoose, E.; Truong, T.; et al. In vivo antitumor activity of MEK and phosphatidylinositol 3-kinase inhibitors in basal-like breast cancer models. Clin. Cancer Res. 2009, 15, 4649-4664. [CrossRef]

170. Zhang, Y.; Cao, H.; Yu, Z.; Peng, H.-Y.; Zhang, C.-J. Curcumin inhibits endometriosis endometrial cells by reducing estradiol production. Iran. J. Reprod. Med. 2013, 11, 415-422.

171. Liang, Y.-J.; Hao, Q.; Wu, Y.-Z.; Wang, Q.-L.; Wang, J.-D.; Hu, Y.-L. Aromatase inhibitor letrozole in synergy with curcumin in the inhibition of xenografted endometrial carcinoma growth. Int. J. Gynecol. Cancer 2009, 19, 1248-1252. [CrossRef] [PubMed]

172. Saydmohammed, M.; Joseph, D.; Syed, V. Curcumin suppresses constitutive activation of STAT-3 by up-regulating protein inhibitor of activated STAT-3 (PIAS-3) in ovarian and endometrial cancer cells. J. Cell. Biochem. 2010, 110, 447-456. [CrossRef] [PubMed]

173. Kunnumakkara, A.B.; Anand, P.; Aggarwal, B.B. Curcumin inhibits proliferation, invasion, angiogenesis and metastasis of different cancers through interaction with multiple cell signaling proteins. Cancer Lett. 2008, 269, 199-225. [CrossRef] [PubMed]

174. Anto, R.J.; Mukhopadhyay, A.; Denning, K.; Aggarwal, B.B. Curcumin (diferuloylmethane) induces apoptosis through activation of caspase-8, BID cleavage and cytochrome $c$ release: Its suppression by ectopic expression of Bcl-2 and Bcl-xl. Carcinogenesis 2002, 23, 143-150. [CrossRef] [PubMed]

175. Collett, G.P.; Campbell, F.C. Curcumin induces c-jun N-terminal kinase-dependent apoptosis in HCT116 human colon cancer cells. Carcinogenesis 2004, 25, 2183-2189. [CrossRef] [PubMed]

176. Choudhuri, T.; Pal, S.; Das, T.; Sa, G. Curcumin selectively induces apoptosis in deregulated cyclin D1-expressed cells at G2 phase of cell cycle in a p53-dependent manner. J. Biol. Chem. 2005, 280, 20059-20068. [CrossRef]

177. Jana, N.R.; Dikshit, P.; Goswami, A.; Nukina, N. Inhibition of proteasomal function by curcumin induces apoptosis through mitochondrial pathway. J. Biol. Chem. 2004, 279, 11680-11685. [CrossRef]

178. Marino, J.L.; Holt, V.L.; Chen, C.; Davis, S. Shift work, hCLOCK T3111C polymorphism, and endometriosis risk. Epidemiology 2008, 19, 477-484. [CrossRef]

179. Mosher, A.A.; Tsoulis, M.W.; Lim, J.; Tan, C.; Agarwal, S.K.; Leyland, N.A.; Foster, W.G. Melatonin activity and receptor expression in endometrial tissue and endometriosis. Hum. Reprod. 2019, 34, 1215-1224. [CrossRef]

180. Koc, O.; Gunduz, B.; Topcuoglu, A.; Bugdayci, G.; Yilmaz, F.; Duran, B. Effects of pinealectomy and melatonin supplementation on endometrial explants in a rat model. Eur. J. Obstet. Gynecol. Reprod. Biol. 2010, 153, 72-76. [CrossRef]

181. Chuffa, L.D.A.; Lupi, L.A.; Cucielo, M.S.; Silveira, H.S.; Reiter, R.J.; Seiva, F.R.F. Melatonin Promotes Uterine and Placental Health: Potential Molecular Mechanisms. Int. J. Mol. Sci. 2019, 21, 300. [CrossRef] [PubMed]

182. Cetinkaya, N.; Attar, R.; Yildirim, G.; Ficicioglu, C.; Ozkan, F.; Yilmaz, B.; Yesildaglar, N. The effects of different doses of melatonin treatment on endometrial implants in an oophorectomized rat endometriosis model. Arch. Gynecol. Obstet. 2015, 291, 591-598. [CrossRef] [PubMed]

183. Güney, M.; Oral, B.; Karahan, N.; Mungan, T. Regression of endometrial explants in a rat model of endometriosis treated with melatonin. Fertil. Steril. 2008, 89, 934-942. [CrossRef] [PubMed]

184. Yilmaz, B.; Kilic, S.; Aksakal, O.; Ertas, I.E.; Tanrisever, G.G.; Aksoy, Y.; Lortlar, N.; Kelekci, S.; Gungor, T. Melatonin causes regression of endometriotic implants in rats by modulating angiogenesis, tissue levels of antioxidants and matrix metalloproteinases. Arch. Gynecol. Obstet. 2015, 292, 209-216. [CrossRef] [PubMed] 
185. Paul, S.; Bhattacharya, P.; Das Mahapatra, P.; Swarnakar, S. Melatonin protects against endometriosis via regulation of matrix metalloproteinase-3 and an apoptotic pathway. J. Pineal Res. 2010, 49, 156-168. [CrossRef] [PubMed]

186. Chuffa, L.G.A.; Seiva, F.R.F.; Fávaro, W.J.; Teixeira, G.R.; Amorim, J.P.A.; Mendes, L.O.; Fioruci, B.A.; Pinheiro, P.F.F.; Fernandes, A.A.H.; Franci, J.A.A.; et al. Melatonin reduces LH, 17 beta-estradiol and induces differential regulation of sex steroid receptors in reproductive tissues during rat ovulation. Reprod. Biol. Endocrinol. 2011, 9, 108. [CrossRef]

187. Zhao, H.; Poon, A.M.; Pang, S.F. Pharmacological characterization, molecular subtyping, and autoradiographic localization of putative melatonin receptors in uterine endometrium of estrous rats. Life Sci. 2000, 66, 1581-1591. [CrossRef]

188. Zhao, H.; Pang, S.F.; Poon, A.M.S. mt(1) Receptor-mediated antiproliferative effects of melatonin on the rat uterine antimesometrial stromal cells. Mol. Reprod. Dev. 2002, 61, 192-199. [CrossRef]

189. Shrestha, S.; Zhu, J.; Wang, Q.; Du, X.; Liu, F.; Jiang, J.; Song, J.; Xing, J.; Sun, D.; Hou, Q.; et al. Melatonin potentiates the antitumor effect of curcumin by inhibiting IKK $\beta / \mathrm{NF}-\kappa \mathrm{B} / \mathrm{COX}-2$ signaling pathway. Int. J. Oncol. 2017, 51, 1249-1260. [CrossRef]

190. Chung, S.; Yao, H.; Caito, S.; Hwang, J.-W.; Arunachalam, G.; Rahman, I. Regulation of SIRT1 in cellular functions: Role of polyphenols. Arch. Biochem. Biophys. 2010, 501, 79-90. [CrossRef]

191. Miki, T.; Xu, Z.; Chen-Goodspeed, M.; Liu, M.; Van Oort-Jansen, A.; Rea, M.A.; Zhao, Z.; Lee, C.C.; Chang, K.-S. PML regulates PER2 nuclear localization and circadian function. EMBO J. 2012, 31, 1427-1439. [CrossRef] [PubMed]

192. Asher, G.; Gatfield, D.; Stratmann, M.; Reinke, H.; Dibner, C.; Kreppel, F.; Mostoslavsky, R.; Alt, F.W.; Schibler, U. SIRT1 regulates circadian clock gene expression through PER2 deacetylation. Cell 2008, 134, 317-328. [CrossRef] [PubMed]

(C) 2020 by the authors. Licensee MDPI, Basel, Switzerland. This article is an open access article distributed under the terms and conditions of the Creative Commons Attribution (CC BY) license (http://creativecommons.org/licenses/by/4.0/). 